\title{
Effect of Selectivity of Herbicides and Plant Growth Regulators used in Sugarcane CROPS ON IMmature STAges OF Trichogramma galloi (HYMENOPTERA: TRICHOGRAMMATIDAE) ${ }^{1}$
}

\author{
Seletividade de Herbicidas e Reguladores de Crescimento de Plantas Utilizados na Cultura da \\ Cana-de-Açúcar para Imaturos de Trichogramma galloi (Hymenoptera: Trichogrammatidae)
}

\author{
OLIVEIRA, H.N. ${ }^{2}$, ANTIGO, M.R. ${ }^{3}$, CARVALHO, G.A. ${ }^{4}$, and GLAESER, D.F. ${ }^{2}$
}

\begin{abstract}
Herbicides and plant growth regulators are often used in sugarcane management. However, the use of non-selective pesticides can cause adverse effects on the efficiency of beneficial insects in integrated pest management. Within this context, this study aimed to evaluate the effect of such products on the immature stages of the parasitoid Trichogramma galloi. Eggs of Diatraea saccharalis containing the parasitoid at the egg-larva stage and at the prepupal and pupal stages were immersed in test solutions of the following pesticides (maximum recommended doses for sugarcane): herbicides clomazone and diuron + hexazinone, and plant growth regulators trinexapac-ethyl and sulfometuron-methyl. The biological properties evaluated were emergence $\left(\mathrm{F}_{1}\right.$ and $\left.\mathrm{F}_{2}\right)$ and number of eggs parasitized by T. galloi $\left(\mathrm{F}_{1}\right)$. The products were classified according to percentage of reduction in emergence and parasitism: harmless (<30\%), slightly harmful (30-79\%), moderately harmful (80-99\%) and harmful $(>99 \%)$. The pesticides evaluated were considered to be harmless or slightly harmful to immature T. galloi and, thus, their use should be preferred for preserving this parasitoid species in sugarcane management programs.
\end{abstract}

Keywords: Saccharum spp., egg parasitoid, Diatraea saccharalis, biological control, chemical control, toxicity.

RESUMO - Herbicidas e reguladores de crescimento de plantas são frequentemente utilizados no manejo da cana-de-açúcar. Entretanto, o uso de compostos não seletivos pode prejudicar a eficiência de insetos benéficos no manejo integrado de pragas. Nesse contexto, avaliou-se o efeito desses produtos sobre as fases imaturas do parasitoide Trichogramma galloi. Ovos de Diatraea saccharalis contendo o parasitoide no periodo de ovo-larva e nas fases de pré-pupa e pupa foram imersos em caldas dos produtos avaliados (doses máximas recomendadas para a cana-de-açúcar), sendo eles: os herbicidas clomazone e diuronthexazinone e os reguladores de crescimento de plantas sulfometuron-methyl e trinexapac-ethyl. As características biológicas avaliadas foram a emergência (gerações $F_{1}$ e $F_{2}$ ) e o número de ovos parasitados por T. galloi $\left(F_{1}\right)$. Os produtos foram classificados, conforme percentual de redução da emergência e parasitismo, em: inócuo (<30\%), levemente prejudicial (30 a 79\%), moderadamente prejudicial (80 a 99\%) e prejudicial (>99\%). Os compostos avaliados foram classificados como inócuos ou levemente prejudiciais aos imaturos de T. galloi e, por isso, devem ser preferidos, visando à preservação dessa espécie de parasitoide em programas de manejo da cana-de-açúcar.

Palavras-chave: Saccharum spp., parasitoide de ovos, Diatraea saccharalis, controle biológico, controle químico, toxicidade.

Recebido para publicação em 6.7.2013 e aprovado em 26.10.2013.

2 Embrapa Agropecuária Oeste, Dourados, MS, Brasil, < harley.oliveira@embrapa.br >; ${ }^{3}$ Universidade Federal da Grande Dourados, Dourados, MS, Brasil; ${ }^{4}$ Universidade Federal de Lavras, Lavras, MG, Brasil. 


\section{INTRODUCTION}

Sugarcane plays an important role in the Brazilian economy, mainly because of the production of sugar and ethanol by sugarcane industries: Brazil is the world leader in this sector (Guia ..., 2009; Portela et al., 2011). This success is partly due to the increase of both productive areas and total productivity, combined with good market prospects (Christofolleti et al., 2005). Such prospects are associated with the need to use new methods for producing more sustainable technologies: for instance, provision of credits in the carbon market, or as alternative fuel production aimed at reducing the use of energy produced from non-renewable sources (Santos, 2008).

Sugarcane productivity is often hampered by several factors, including the incidence of borer Diatraea saccharalis (Fabricius, 1794) (Lepidoptera, Crambidae), which is noteworthy because it causes great economic losses. After mating, females of this insect lay eggs on the leaves of the cane, and after the outbreak of caterpillars, they feed on the leaf parenchyma, penetrating the thatch from the third instar. Within the thatch, caterpillars open galleries as it feeds, thus injuring the plant (Botelho, 1992; Pinto et al. 2006).

An alternative to control this pest is through the larval parasitoid Cotesia flavipes Cameron, 1981 (Hymenoptera: Braconidae) and egg parasitoid Trichogramma galloi-Zucchi, 1988 (Hymenoptera: Trichogrammatidae) (Lima Filho \& Lima, 2003). T. galloi has the advantage of controlling this insect pest still at the egg stage, thereby preventing the outbreak of caterpillars and damage to the crop. Furthermore, the parasitoid has also been established in mass production systems for commercialization (Martins et al., 2011), which enhances its use.

Several chemicals are used in sugarcane management, for example herbicides, which are used in weed control (Carvalho et al. 2010a), and plant growth regulators, which are applied in order to anticipate the maturation process, improve the quality of raw material, optimize agribusiness and economic results, and assist in harvest planning (Caputo et al., 2008). However, studies show that the different products used in the management of agricultural crops may adversely affect natural enemies both at the adult and the immature stages, reducing the efficiency of biological control (Cônsoli et al., 2001; Carmo et al., 2010a; Maia et al., 2010; Stefanello Junior et al., 2011).

Selectivity studies with herbicides in maize crops showed detrimental effects on immature Trichogramma pretiosum - Riley, 1879 (Hymenoptera: Trichogrammatidae) (Stefanello Junior et al., 2011); evaluations using immature Telenomus remus - Nixon, 1937 (Hymenoptera: Scelionidae) in soy have shown adverse effects of herbicides on this parasitoid (Carmo et al., 2010b). For plant growth regulators, there are no studies of their effect on parasitoids.

As the application of phytosanitary products directly affects sugarcane leaves, where also females of $D$. saccharalis lay their eggs, chemicals used in these crops may have contact with the eggs of insect pests; hence the immature stage of $T$. galloi can be affected, as this parasitoid develops at this stage in the host. In this context, the aim of the present study was to evaluate the selectivity of herbicides and plant growth regulators used in sugarcane for immature T. galloi, in order to obtain information that may contribute to maintaining the population size of $T$. galloi in this agroecosystem.

\section{MATERIAL AND METHODS}

The effects of pesticides used in sugarcane crops on immature parasitoid $T$. galloi were evaluated in the laboratory, using herbicides clomazone $\left(800 \mathrm{~g} \mathrm{~L}^{-1}\right)$ and hexazinone + diuron $\left(488 \mathrm{~g} \mathrm{~kg}^{-1}+142 \mathrm{~g} \mathrm{~kg}^{-1}\right)$, and plant growth regulators sulfometuron-methyl $\left(750 \mathrm{~g} \mathrm{~kg}^{-1}\right)$ and trinexapac-ethyl $\left(250 \mathrm{~g} \mathrm{~L}^{-1}\right)$. The number in parentheses refers to the concentration of active ingredient in the commercial product; for all products, the evaluation was based on the highest doses recommended for the crop (Agrofit, 2011). Using the maximum dose when testing phytosanitary products for toxicity in laboratory conditions is recommended by the International Organization for Biological and Integrated Control of Noxious Animals and Plants (IOBC) (Hassan et al., 2000). 
In order to evaluate the effect of the products on the emergence and parasitism of $T$. galloi of $\mathrm{F}_{1}$ generation, the newly emerged parasitoids were kept in a plastic container $(12.5 \mathrm{~cm} \times 9 \mathrm{~cm}$ diameter) containing a trickle of honey for 24 hours for mating purposes. After this period, three females of $T$. galloi by replicate and up to 24 hours of age were sexed based on the characteristics of their antennas and placed in a glass tube $(8.5 \mathrm{~cm}$ height $\mathrm{x} 2.5 \mathrm{~cm}$ diameter) containing a droplet of honey. In this tube, the females received 60 eggs of $D$. saccharalis aged up to 24 hours which had been oviposited on paper towels. The number of 60 eggs per replicate was used because of previous observations made in the laboratory, where it was found that the maximum number of eggs of $D$. saccharalis parasitized by a female $T$. galloi was 20. After 24 hours, the females were discarded, and the supposedly infected eggs were kept in a environmental chamber at $23 \pm 2{ }^{\circ} \mathrm{C}$ with relative humidity $60 \pm 10 \%$ and photoperiod of 14 hours until the parasitoids could reach the egg-larva stage and the prepupal or pupal stages $10-24 \mathrm{~h}, 72-96 \mathrm{~h}$ and $168-192 \mathrm{~h}$ after parasitism, respectively), according to the methodology proposed by Cônsoli et al. (2001) and Carvalho et al. (2010b).

The eggs of $D$. saccharalis containing T. galloi in each of the abovementioned stages of development were immersed for five seconds in aqueous dilutions and / or distilled water (control), according to methodology by Carvalho et al. (2003) and Moura et al. (2005). To remove the excess of liquid of the dilutions from the surface of the eggs, they were kept for one hour at room temperature and thereafter transferred to glass tubes $(8.5 \mathrm{~cm} \times 2.5 \mathrm{~cm}$ diameter) and kept under the same conditions described above, until the emergence of the parasitoid.

The effects of the compounds on the specimens of $\mathrm{F}_{1}$ generation of $T$. galloi were assessed for percentage of emergence $=$ (number of eggs of the parasitoid with exit holes / total number of parasitized eggs) x 100) and number of parasitized eggs per female in 24 hours $=($ number of parasitized eggs $/ 3)$.

To assess the effects of the compounds on the specimens of $\mathrm{F}_{1}$ generation, surviving adults of $T$. galloi from each treatment were previously fed with droplets of honey; subsequently, three females per replicate aged up to 24 hours received 60 eggs of $D$. saccharalis (not exposed to chemicals). The parasitoids remained in contact with the eggs for 24 hours; after that, they were removed and kept at $23 \pm 2{ }^{\circ} \mathrm{C}$, with relative humidity of $60 \pm 10 \%$ and photoperiod of 14 hours until the emergence of parasitoids. The percentage of emergence of insects of $F_{2}$ generation was evaluated.

The products evaluated were classified as for the percentage of reduction (PR) in the beneficial capacity of parasitoids (parasitism and emergence): harmless, class $1(<30 \%)$, slightly harmful, class 2 (30-79\%), moderately harmful, class 3 (80 to 99\%) and harmful, class 4 (> 99\%), as recommended by IOBC (Sterk et al. 1999). The following formula was used to calculate PR:

$\mathrm{PR}=100-\left(\frac{\text { overall mean percentage of treatment with product }}{\text { overall mean percentage of control }} \times 100\right)$

The experiments used a completely randomized factorial $3 \times 5$ design (three periods of development $\mathrm{x}$ four chemicals and control), with 15 replicates. The data were submitted to analysis of variance (ANOVA) and the means of the treatments were compared at the 5\% level of significance ( $p<0.05)$ by the Scott-Knott test, using the statistical software SISVAR 5.3 (Ferreira, 2010).

\section{RESULTS AND DISCUSSION}

It was found that all the compounds applied on eggs of $D$. saccharalis containing immature T. galloi during egg-larva and prepupal stages reduced the emergence of parasitoids of F1 generation. Diuron + hexazinone and trinexapac-ethyl were the most harmful to the parasitoid at the egg-larva stage, and clomazone, at the prepupal stage. At the pupal stage, only diuron + hexazinone reduced this biological property (Table 1).

Differences between the stages of development as for the emergence of insects of F1 generation were observed for diuron + hexazinone and trinexapac-ethyl, and the egglarva stage was the most susceptible to their effects (Table 1). At the egg-larva stage, the parasitoids tend to be more sensitive, probably 
Tabela 1 - Percentage of emergence $( \pm \mathrm{PE})$ of Trichogramma galloi ( $\mathrm{F}_{1}$ generation) originated from eggs of Diatraea saccharalis treated with chemicals containing parasitoids during egg-larva, prepupal and pupal stages

\begin{tabular}{|l|c|c|c|}
\hline \multirow{2}{*}{\multicolumn{1}{|c|}{ Treatment }} & \multicolumn{3}{c|}{ Stages of development } \\
\cline { 2 - 4 } & Egg-larva & Prepupal & Pupal \\
\hline Control & $64.58 \pm 4.62 \mathrm{aA}$ & $62.53 \pm 5.05 \mathrm{aA}$ & $50.73 \pm 6.10 \mathrm{aA}$ \\
\hline Clomazone & $43.78 \pm 7.10 \mathrm{bA}$ & $38.67 \pm 7.56 \mathrm{cA}$ & $27.36 \pm 4.35 \mathrm{bB}$ \\
\hline Diuron+hexazinone & $28.85 \pm 5.98 \mathrm{cB}$ & $48.95 \pm 7.79 \mathrm{bA}$ & $50.40 \pm 4.49 \mathrm{aA}$ \\
\hline Trinexapac-ethyl & $19.33 \pm 5.69 \mathrm{cB}$ & $39.77 \pm 4.71 \mathrm{bA}$ & $51.65 \pm 7.01 \mathrm{aA}$ \\
\hline Sulfometuron-methyl & $42.78 \pm 5.68 \mathrm{bA}$ & $44.65 \pm 6.85 \mathrm{bA}$ & $\mathrm{aA}$ \\
\hline
\end{tabular}

Means followed by the same letter, lowercase in the column and uppercase on the line, do not differ by the Scott-Knott test (p>0.05).

because of the longer period of penetration of the product through the chorion of the host egg until emergence and also increased activity of the larvae, when compared to the prepupal and pupal stages, which corroborates the results obtained by Carvalho et al. (2001). Furthermore, the penetration ability of the products depends on their physicochemical properties, such as their lipophilicity (Crespo et al. 2002), and also the properties of the host, which vary depending on the species, age and stage of development of the egg (Cônsoli et al. 1999a, b).

As for toxicity, according to criteria of IOBC, herbicides and plant growth regulators were considered to be harmless or slightly harmful to the emergence of parasitoids of $\mathrm{F} 1$ generation of $T$. galloi, regardless of stage of development (Table 2). At the egg-larva stage, all products were considered to be slightly harmful and showed reductions in emergency ranging between 32 and $70 \%$.

This selectivity of the evaluated products can be associated with two hypotheses: the absence or low toxicity of these compounds, or their low penetrating capacity into the membranes of the chorion of the host egg, as described by Carvalho et al. (2001), who studied the effects of some pesticides on T. pretiosum.

Studies on the effect of diuron + hexazinone, trinexapac-ethyl and methylsulfometuron on immature parasitoids of the genus Trichogramma were not found in the literature. Carmo et al. (2010a) reported that clomazone was harmeless to T. pretiosum on eggs of Anagasta kuehniella (Zeller, 1879) (Lepidoptera: Pyralidae) when used at the recommended dose for soybean crops, a smaller dose than the one assessed in the present study (maximum dose for sugarcane crops).

As for parasitism, only trinexapac-ethyl reduced the number of eggs parasitized by females of F1 generation, when the eggs of $D$. saccharalis were treated with this herbicide containing $T$. galloi during egg-larva stage (Table 3), with a reduction of $44.5 \%$ (Table 4). At the prepupal stage, all products were harmless to parasitism (Tables 3 and 4).

At the pupal stage, the products did not have hamper parasitism capacity (Table 3 ). However, the classification of products at this stage varied between harmless for hexazinone + diuron and sulfometuron-methyl and slightly harmless for clomazone and trinexapac-ethyl. Treatments based on clomazone and trinexapac-ethyl caused reductions in parasitism of $T$. galloi, compared with the control (Table 4). These reductions probably occurred because precisely at this stage, there was emergence of adults with deformed wings. Deformed insects may have limitations, such as difficulty in feeding, mating and parasiting, thus affecting their parasitism capacity. It is noteworthy that reductions in biological properties of insects (e.g. fertility), as a result of the action of sublethal pesticides, have been reported in the literature (Carvalho et al., 1999; Foerster, 2002).

An evaluation of the effects of compounds on parasitism capacity between the stages of development of $T$. galloi showed no significant differences (Table 3).

For the emergence of the specimens of $\mathrm{F}_{2}$ generation of $T$. galloi, originated from eggs of $D$. saccharalis containing the parasitoid during 
Table 2 - Reduction in emergence (RE) of Trichogramma galloi ( $\mathrm{F}_{1}$ generation) originated from eggs of Diatraea saccharalis treated with chemicals containing parasitoids during egg-larva, prepupal and pupal stages, and toxicity classes of compounds

\begin{tabular}{|c|c|c|c|c|c|c|}
\hline \multirow{3}{*}{ Treatment } & \multicolumn{6}{|c|}{ Development } \\
\hline & \multicolumn{2}{|c|}{ Egg-larva } & \multicolumn{2}{|c|}{ Prepupa } & \multicolumn{2}{|c|}{ Pupa } \\
\hline & $\mathrm{RE}^{1 /}$ & Class $^{2 \prime}$ & $\mathrm{RE}^{1 /}$ & Class $^{2 /}$ & $\mathrm{RE}^{1 /}$ & Class $^{2}$ \\
\hline Clomazone & 32.20 & 2 & 38.15 & 2 & 19.02 & 1 \\
\hline Diuron+hexazinone & 55.32 & 2 & 21.71 & 1 & 56.32 & 2 \\
\hline Trinexapac-ethyl & 70.06 & 2 & 36.39 & 2 & 19.55 & 1 \\
\hline Sulfometuron-methyl & 33.75 & 2 & 28.59 & 1 & 17.55 & 1 \\
\hline
\end{tabular}

${ }^{1 /}$ Mean percentage of reduction in emergency. ${ }^{2 /}$ Toxicity index as recommended by IOBC (Sterk et al., 1999).

Table 3 - Number ( \pm PE) of eggs parasitized by females of Trichogramma galloi of $\mathrm{F}_{1}$ generation, derived from eggs of Diatraea saccharalis treated with chemicals containing parasitoids during egg-larva, prepupal and pupal stages

\begin{tabular}{|l|c|c|c|}
\hline \multirow{2}{*}{\multicolumn{1}{|c|}{ Treatment }} & \multicolumn{3}{c|}{ Development } \\
\cline { 2 - 4 } & Egg-larva $^{1 /}$ & Prepupa $^{1 /}$ & Pupa $^{1 /}$ \\
\hline Control & $16.67 \pm 2.49 \mathrm{aA}$ & $11.44 \pm 2.57 \mathrm{aA}$ & $10.60 \pm 2.08 \mathrm{bA}$ \\
\hline Clomazone & $12.06 \pm 3.14 \mathrm{aA}$ & $14.66 \pm 3.56 \mathrm{aA}$ & $05.06 \pm 2.01 \mathrm{bA}$ \\
\hline Diuron+hexazinone & $14.93 \pm 3.31 \mathrm{aA}$ & $12.25 \pm 2.88 \mathrm{aA}$ & $17.20 \pm 5.96 \mathrm{aA}$ \\
\hline Trinexapac-ethyl & $09.26 \pm 2.91 \mathrm{bA}$ & $16.66 \pm 4.93 \mathrm{aA}$ & $07.13 \pm 2.88 \mathrm{bA}$ \\
\hline Sulfometuron-methyl & $11.40 \pm 2.79 \mathrm{aA}$ & $14.33 \pm 4.15 \mathrm{aA}$ & $13.40 \pm 2.81 \mathrm{aA}$ \\
\hline
\end{tabular}

1/ Means followed by the same letter, lowercase and uppercase in the column on the line, do not differ by the Scott-Knott test ( $>0.05$ ).

Table 4 - Percentage of reduction (PR) in the parasitism of female Trichogramma galloi of $\mathrm{F}_{1}$ generation, derived from eggs of Diatraea saccharalis treated with chemicals containing parasitoids during egg-larva and prepupal and pupal stages, and toxicity classes of compounds

\begin{tabular}{|c|c|c|c|c|c|c|}
\hline \multirow{3}{*}{ Treatment } & \multicolumn{6}{|c|}{ Development } \\
\hline & \multicolumn{2}{|c|}{ Egg-larva } & \multicolumn{2}{|c|}{ Prepupa } & \multicolumn{2}{|c|}{ Pupa } \\
\hline & $\mathrm{PR}^{\frac{1 /}{\prime}}$ & Class $^{2 /}$ & $\mathrm{PR}^{1 /}$ & Class $^{2 /}$ & $\mathrm{PR}^{1 / \prime}$ & Class $^{2 \prime}$ \\
\hline Clomazone & 27.65 & 1 & 0 & 1 & 52.26 & 2 \\
\hline Diuron+hexazinone & 10.43 & 1 & 0 & 1 & 0 & 1 \\
\hline Trinexapac-ethyl & 44.45 & 2 & 0 & 1 & 32.73 & 2 \\
\hline Sulfometuron-methyl & 31.61 & 2 & 0 & 1 & 0 & 1 \\
\hline
\end{tabular}

${ }^{1 /}$ Mean percentage of reduction in parasitism. ${ }^{2 /}$ Toxicity index as recommended by IOBC (Sterk et al., 1999).

the egg-larva and pupal stages, no significant differences were found (Table 5). For the prepupal stage, clomazone and sulfometuronmethyl reduced the emergence of $F_{2}$ generation, compared with the control, and the products were classified as slightly harmful, with a percentage of reduction of 30.3 and $36.0 \%$, respectively (Tables 5 and 6).

When comparing the influence of the products on the emergence of $\mathrm{F}_{2}$ at different immature stages of $T$. galloi, only trinexapac-ethyl showed no change (Table 5).

In general, herbicides and plant growth regulators used in this study were selective for immature T. galloi and, therefore, can be used in sugarcane crops without compromising the integrated pest management of the sugarcane borer, thus preserving this species of parasitoid. 
Table 5 - Emergence $(\%)( \pm \mathrm{PE})$ of Trichogramma galloi of $\mathrm{F}_{2}$ generation derived from females $\left(\mathrm{F}_{1}\right)$ that emerged from eggs of Diatraea saccharalis treated with chemicals containing parasitoids during egg-larva and prepupal and pupal stages.

\begin{tabular}{|l|c|c|c|}
\hline \multirow{2}{*}{ Treatment } & \multicolumn{3}{c|}{ Development } \\
\cline { 2 - 4 } & Egg-larva $^{1 /}$ & Prepupa $^{1 /}$ & Pupa $^{1 /}$ \\
\hline Control & $69.96 \pm 05.33 \mathrm{aA}$ & $75.90 \pm 3.80 \mathrm{aA}$ & $57.12 \pm 07.61 \mathrm{aA}$ \\
\hline Clomazone & $76.39 \pm 05.15 \mathrm{aA}$ & $52.92 \pm 6.09 \mathrm{bB}$ & $49.66 \pm 11.27 \mathrm{aB}$ \\
\hline Diuron+hexazinone & $87.41 \pm 04.45 \mathrm{aA}$ & $71.25 \pm 5.90 \mathrm{aA}$ & $46.06 \pm 11.31 \mathrm{aB}$ \\
\hline Trinexapac-ethyl & $80.80 \pm 03.75 \mathrm{aA}$ & $72.06 \pm 7.41 \mathrm{aA}$ & $67.64 \pm 14.88 \mathrm{aA}$ \\
\hline Sulfometuron-methyl & $87.07 \pm 02.38 \mathrm{aA}$ & $48.56 \pm 8.68 \mathrm{bC}$ & $70.21 \pm 04.56 \mathrm{aB}$ \\
\hline
\end{tabular}

${ }^{1 /}$ Means followed by the same letter, lowercase and uppercase in the column on the line, do not differ by the Scott-Knott test ( $\mathrm{p}>0.05$ ).

Table 6 - Percentage of reduction (PR) in the emergence of Trichogramma galloi of $\mathrm{F}_{2}$ generation originated from females of $\mathrm{F}_{1}$ generation that emerged from eggs of Diatraea saccharalis treated with chemicals containing parasitoids during egg-larva, prepupal and pupal stages and toxicity classes of compounds

\begin{tabular}{|c|c|c|c|c|c|c|}
\hline \multirow{3}{*}{ Treatment } & \multicolumn{6}{|c|}{ Development } \\
\hline & \multicolumn{2}{|c|}{ Egg-larva } & \multicolumn{2}{|c|}{ Prepupa } & \multicolumn{2}{|c|}{ Pupa } \\
\hline & $\mathrm{PR}^{1^{1 /}}$ & Class $^{2 /}$ & $\mathrm{PR}^{1 / /}$ & Class $^{2 /}$ & $\mathrm{PR}^{1 /}$ & Class $^{\underline{2 \prime}}$ \\
\hline Clomazone & 0 & 1 & 30.27 & 2 & 13.06 & 1 \\
\hline Diuron+hexazinone & 0 & 1 & 06.12 & 1 & 19.36 & 1 \\
\hline Trinexapac-ethyl & 0 & 1 & 05.05 & 1 & 0 & 1 \\
\hline Sulfometuron-methyl & 0 & 1 & 36.02 & 2 & 0 & 1 \\
\hline
\end{tabular}

${ }^{1 /}$ Mean percentage of emergence reduction. ${ }^{2 /}$ Toxicity index as recommended by IOBC (Sterk et al., 1999).

\section{ACKNOWLEDGMENTS}

We would like to thank CAPES (Coordination for the Improvement of Higher Education Personnel), CNPq (National Council for Scientific and Technological Development) and Embrapa (Brazilian Agricultural Research Corporation) for their financial support.

\section{LITERATURE CITED}

AGROFIT: Sistema de Agrotóxicos Fitossanitários.

[Brasília, DF]: 2011. Disponível em: <http://

agrofit.agricultura.gov.br/agrofit_cons/

principal_agrofit_cons>. Acesso em: $11 \mathrm{dez} .2011$.

BOTELHO, P. S. M. Quinze anos de controle biológico da Diatraea saccharalis utilizando parasitóides. Pesq. Agropec. Bras., v. 27, p. 255-262, 1992. (Edição Especial)

CAPUTO, M. M. et al. Resposta de genótipos de cana-deaçúcar à aplicação de indutores de maturação. Bragantia, v. 67, n. 1, p. 15-23, 2008.
CARMO, E. L. et al. Seletividade de produtos fitossanitários utilizados na cultura da soja para pupas de Trichogramma pretiosum Riley, 1879 (Hymenoptera: Trichogrammatidae). Arq. Inst. Biol., v. 77, n. 2, p. 283-290, 2010a.

CARMO, E. L.; BUENO, A. F.; BUENO, R. C. O. F. Pesticide selectivity for the insect egg parasitoid Telenomus remus. BioControl, v. 55, n. 4, p. 455-464, 2010b.

CARVALHO, F. T. et al. Controle de dez espécies daninhas em cana-de-açúcar com o herbicida mesotrione em mistura com ametryn e metribuzin. Planta Daninha, v. 28, n. 3, p. 585-590, 2010a.

CARVALHO, G. A. et al. Effect of chemical insecticides used in tomato crops on immature Trichogramma pretiosum (Hymenoptera: Trichogrammatidae). R. Colom. Entomol., v. 36, n. 1, p. 10-15, 2010b.

CARVALHO, G. A. et al. Seletividade de alguns produtos fitossanitários a duas linhagens de Trichogramma pretiosum Riley, 1879 (Hymenoptera: Trichogrammatidae).

Ci. Agrotec., v. 25, n. 3, p. 583-591, 2001. 
CARVALHO, G. A. et al. Ação residual de alguns inseticidas pulverizados em plantas de tomateiro sobre duas linhagens de Trichogramma pretiosum Riley, 1879 (Hymenoptera: Trichogrammatidae) em casa-de-vegetação. Ci. Agrotec., v. 23, n. 4, p. 770-775, 1999.

CARVALHO, G. A.; PARRA, J. R. P.; BAPTISTA, G. C. Bioatividade de produtos fitossanitários utilizados na cultura do tomateiro (Lycopersicon esculentum Mill.) a Trichogramma pretiosum Riley, 1879 (Hymenoptera: Trichogrammatidae) nas gerações $\mathrm{F}_{1}$ e $\mathrm{F}_{2}$. Ci. Agrotec., v. 27, n. 2, p. 261-270, 2003.

CHRISTOFFOLETI, P. J. et al. Manejo de plantas daninhas na cultura da cana-de-açucar: novas moléculas herbicidas. In: SIMPÓSIO DE TECNOLOGIA DE PRODUÇÃO DE CANA-DE-AÇÚCAR, 2., 2005, Piracicaba. Anais... Piracicaba: IPNI, 2005. Disponível em: <http://www.potafos. org/ppiweb/pbrazil.nsf/926048f0196c9d4285256983005 c64de/e5595a4efa1a6821032570d8004576de/\$FILE/Anais\%2 0Jacob\%20Christofoletti.pdf>. Acesso em: 11 dez. 2011.

CÔNSOLI, F. L.; BOTELHO, P. S. M.; PARRA, J. R. P. Selectivity of insecticides to the egg parasitoid Trichogramma galloi Zucchi, 1988 (Hym., Trichogrammatidae). J. Appl. Entomol., v. 125, n. 1-2, p. 37-43, 2001.

CÔNSOLI, F. L. et al. Developmental time and characteristics of the immature stages of Trichogramma galloi and Trichogramma pretiosum Riley (Hymenoptera, Trichogrammatidae). R. Bras. Entomol., v. 43, n. 2, p. 271-275, 1999a.

CÔNSOLI, F. L.; KITAJIMA, E. W.; PARRA, J. R. P. Ultrastructure of the natural and factitious host eggs of Trichogramma galloi and T. pretiosum Riley (Hymenoptera, Trichogrammatidae). Int. J. Insect Morphol. Embryol., v. 28, n. 3, p. 211-229, 1999 b.

CRESPO, A. L. B. et al. Seletividade fisiológica de inseticidas a Vespidae predadores de Ascia monuste orseis. Pesq. Agropec. Bras., v. 37, n. 3, p. 237-242, 2002.

FERREIRA, D. F. SISVAR 5.3. Sistema de Análises

Estatísticas. Lavras: Universidade Federal de Lavras, 2010.

FOERSTER, L. A. Seletividade de inseticidas a predadores e parasitóides. In: PARRA, J. R. P. et al. (Ed.). Controle biológico no Brasil: parasitóides e predadores. São Paulo: Manole, 2002. p. 94-114.

GUIA da cana-de-açúcar: avanço científico beneficia o país. São Paulo: Conselho de Informações sobre Biotecnologia, 2009. 19 p. Disponível em: <http://www.ebah.com.br/content/ ABAAABHZ4AI/guia-cana>. Acesso em: 10 set. 2011.
HASSAN, S. A. et al. A laboratory method to evaluate the side effects of plant protection products on Trichogramma cacoeciae Marchal (Hym., Trichogrammatidae). In:

CANDOLFI, M. P. et al. (Ed.). Guidelines to evaluate side-effects of plant protection products to nontarget arthropods. Montfavet: IOBC/ WPRS, 2000. p. 107-119.

LIMA FILHO, M.; LIMA, J. O. G. Diatraea saccharalis (Fabr.) em cana-de-açúcar na região Norte do Estado do Rio de Janeiro: flutuação populacional e parasitismo de ovos por Trichogramma spp. R. Univ. Rural., v. 22, n. 2, p. 33-44, 2003.

MAIA, J. B. et al. Selectivity of insecticides used in corn crops to adult Trichogramma atopovirilia (Hymenoptera: Trichogrammatidae). R. Colomb. Entomol., v. 36, n. 2, p. 202-206, 2010.

MARTINS, A. L. et al. Eficiência de Trichogramma galloi no combate à Diatraea saccharalis na cana-de-açúcar em Passos-MG-Brasil. R. Verde, v. 6, n. 4, p. 190-195, 2011.

MOURA, A. P.; CARVALHO, G. A.; RIGITANO, R. L. O. Toxicidade de inseticidas utilizados na cultura do tomateiro a Trichogramma pretiosum. Pesq. Agropec. Bras., v. 40, n. 3, p. 203-210, 2005.

PORTELA, G. L. F. et al. Infestação de Diatraea spp. em diferentes variedades de cana-de-açúcar em União-PI.

R. Caatinga, v. 24, n. 1, p. 149-152, 2011.

PINTO, A. S.; CANO, M. A. V.; SANTOS, E. M. A brocada-cana, Diatraea saccharalis. In: PINTO, A. S. (Org.).

Controle de pragas da cana-de-açúcar. Sertãozinho:

Biocontrol, 2006. p. 15-20. (Boletim Técnico

Biocontrol, 1).

SANTOS, J. M. Cultura da cana-de-açúcar, crédito de carbono e o desafio do desenvolvimento sustentável. 2008. 126 f. Dissertação (Mestrado em Sociedade, Tecnologia e Meio Ambiente) - Centro Universitário de Anápolis, Unievangélica, Anápolis, 2008.

STEFANELLO JÚNIOR, G. J. et al. Seletividade de herbicidas registrados para a cultura do milho aos estádios imaturos de Trichogramma pretiosum (Hymenoptera: Trichogrammatidae). Planta Daninha, v. 29, p. 1069-1077, 2011. (Número Especial)

STERK, G. et al. Results of the seventh joint pesticide testing programme carried out by the IOBC/WPRS-Working Group 'Pesticides and Beneficial Organisms'. BioControl, v. 44, n. 1, p. 99-117, 1999. 